FACTA UNIVERSITATIS

Series: Teaching, Learning and Teacher Education Vol. 3, № 2, 2019, pp. 131 - 146

https://doi.org/10.22190/FUTLTE1902131C

Original research paper

\title{
EDUCATION AS A FACTOR IN THE DEVELOPMENT OF MUSICAL TASTE
}

\author{
UDC 37.036- 316.75(497.11); 78:37
}

\section{Predrag Cvetičanin}

Faculty of Arts, University of Niš

\begin{abstract}
In this paper, the influence of the respondents' level of education, and that of their parents, on the development of musical taste is analyzed. The analyses are based on the survey research into the cultural practices of the citizens of Serbia from 2005, 2010, 2015, and 2017, coordinated by the author. The introductory part of the text provides a brief overview of the three sociological standpoints on association between taste and belonging to social collectives, whose applicability has been tested in the research on cultural practices in Serbia. The following section provides the results of a longitudinal research on the manifested preferences for various types of music genres in Serbia and attitudes that the respondents had towards numerous music genres which were analyzed in these studies. In the third part of the paper, we focus on the research results related to classical music and the opera and explore which social factors influence the formation of aesthetic preferences for these music genres in Serbia. The conclusion contains a brief presentation of implications of the findings on the activities of audience development for classical music that is mostly studied in the course "Musical Culture" in elementary and secondary schools. They include, as a prerequisite, the improvement of the cultural offer in local communities; the need for audience development to start early in childhood and to be continuous; the requirement for teachers to be aware of the symbolic aspects of musical tastes related to social divisions; and the focus on children acquiring skills of deciphering cultural codes, and not so much on acquiring theoretical knowledge on the history of art or musical instruments.
\end{abstract}

Key words: musical taste, classical music, education, audience development

Received October 21, 2019/Accepted November 28, 2019

Corresponding author: Predrag Cvetičanin

Faculty of Arts, University in Niš, Kneginje Ljubice 10, 18000 Niš, Serbia

Phone: +381 18522396 •E-mail: pcveticanin@gmail.com

C 2019 by University of Niš, Serbia | Creative Commons License: CC BY-NC-ND 


\section{INTRODUCTION}

Sociological interest in the study of cultural practices of the audience is focused on studying how trends of cultural participation and tastes explore, reproduce, and potentially transform social collectives. The traditional sociological approach to the study of cultural participation analyzes the association between cultural consumption and key social forms of grouping (such as gender, age groups, ethnic groups, classes, race, etc.). In contemporary social theory three standpoints have emerged on the topic, which in the paper "Social Stratification and Cultural Consumption: Music in England", Tak Wing Chan and John H. Goldthorpe label as a) a homology thesis; b) individualization thesis; and c) the omnivore/ univore thesis.

Well-known representatives of the homology thesis are the French sociologist Pierre Bourdieu and the American sociologist Herbert Gans. Simply put, this thesis presupposes a match between social and cultural stratification - those who assume higher social positions consume works of high or elite culture, while those holding lower social positions prefer some form of popular (commercial or folk) culture, with numerous social and cultural layers between them. The individualization thesis is in stark contrast to this type of understanding. It either generally denies the influence of social structure on the shaping of cultural practices, or assumes that this influence existed for some time in the past, but that today, in developed, post-industrial societies, it has been lost. According to the authors who support this standpoint, instead of being an expression of one's position in the social stratification and a part of classification struggles, tastes, cultural consumption and lifestyles have become a part of the "self-realization" project in contemporary societies. According to the omnivore/univore thesis, which was formulated by the American sociologist Richard Peterson, the conception of homology is outdated, not because cultural practices are losing their social basis, but due to the fact that new forms of association among them are emerging. The cultural consumption of social elite no longer differs from the consumption of the lower layers of the social ladder in that social elite consume elite art, but the distinction is based on the fact that the intensity of their cultural consumption is greater and the extent of their cultural consumption broader (it includes works of art from all levels of culture ${ }^{1}$ ). In what follows, we tested which of the three above-mentioned thesis on the association between belonging to social collectives and certain types of taste could find confirmation in Serbia.

The subject matter of this article is the influence of social factors, in particular education, on the development of musical taste of children in Serbia. Its main goal is to identify the implications of the research findings for the activities of audience development for classical music in elementary and secondary schools. This was done by carrying out several tasks. First, we presented the results of longitudinal research of the manifested preferences for various types of music genres in Serbia, and the attitudes that the respondents had towards numerous music genres. Secondly, we studied the influence of education on the formation of musical taste, especially in relation to the aesthetic preferences for classical music and the opera. Thirdly, we pointed out the differences in social context that influence audience development in Serbia and pinpointed the implications that teachers of the "Musical Culture" course in elementary and secondary schools should bear in mind during these activities.

\footnotetext{
${ }^{1}$ Because they consume works of art from high, elite culture, and works of art from popular culture, Peterson refers to them as omnivores, a term which originated in the field of biology studies (Peterson, 1992; 2005; Peterson and Simkus, 1992; Peterson and Kern, 1996). See also contemporary polemics between Chan (2019) and Flemmen, M.P, Jarness, V. and Rosenlund, L. (2019).
} 


\section{DATA AND METHOD}

This text is based on the results of four survey research projects, carried out on national proportional probability samples from 2005 to 2017: "Cultural Needs, Habits and Tastes of the Citizens of Serbia and Macedonia" (2005, CCI, supported by European Cultural Foundation, 1364 respondents); "Cultural Practices of the Citizens of Serbia" (2010, The Center for Studies in Cultural Development, 1490 respondents)"; "Life Strategies and Survival Strategies of Individuals and Households in the Societies of South-East Europe during the time of economic crisis" (2015, Centre for Empirical Cultural Studies of SouthEast Europe, supported by Swiss National Science Foundation, 1000 respondents) and "Closing the Gap Between Formal and Informal institutions in the Balkans INFORM" (Centre for Empirical Cultural Studies of South-East Europe, Horizon 2020 project, 1127 respondents) ${ }^{3}$. As indicated from the titles of the research projects, the first two dealt exclusively with the cultural practices of the citizens of Serbia, while in the other two, whose basic topic was not related to culture, the survey questionnaire included a section with a significant number of items related to cultural participation and taste.

In the analysis of the obtained data, in addition to the basic descriptive statistics techniques, we used the Multiple Correspondence Analysis (MCA) and a binominal logistic regression analysis. The Multiple Correspondence Analysis is an inductive, exploratory technique with the main goal of identifying hidden structures within the data. However, with the introduction of so-called passive or supplementary variables it can also be used for explanatory purposes. Taking advantage of what MCA allows us to do, we reconstructed the maps of taste - preferences for certain music genres - in 2005, 2010, 2015 and 2017 and then projected onto them, as supplementary variables, the highest level of education of the respondents and their parents, and analyzed the associations which exist between these two groups of variables. On the other hand, the regression analysis was used to determine which social factors correlate with tastes related to classical music. As predictors, we used the gender and age of the respondents, their place of residence, average monthly income per household, and the level of education of the respondents and that of their parents.

\section{FAVORITE Music GENRES IN SERBia (2005 - 2017)}

In the research survey on taste, two approaches are mainly used: a) in the first one, taste is operationalized through the verbally expressed evaluations of specific pieces of art, or verbally expressed preferences for certain art genres; b) in the second, taste is studied through respondents practices - attending a certain type of cultural event (for example, rock 'n' roll concerts or folk and classical music concerts), watching certain movie genres, reading the books of various authors, etc. In this text we present the results obtained within the first approach.

As can be seen in graphs $1 \mathrm{~A}-1 \mathrm{C}$, the results indicate that the prevalence of types of taste - that is, of the manifested aesthetic preferences for certain types of genres in Serbia - is rather stable. The most popular music genre in Serbia is traditional folk music (the

\footnotetext{
${ }^{2}$ The results of these studies were also presented in Cvetičanin (2007), Cvetičanin and Milankov (2011a), Cvetičanin and Popescu (2011b) and Cvetičanin ed. (2012)

${ }^{3}$ In the case of all these studies, a stratified multistage probablity sample was used. Samples of this size enable the evaluation of the parameters of the population at a confidence interval of $95 \%$ and an error ranging from $2.5 \%$ (when the maximal variance is $50 \%$ ) to $1.5 \%$ (when the variance is $10 \%$ ).
} 
genre preferred by anywhere between $25.2 \%$ (2005) and $34.2 \%$ of the respondents (2017)); then, old town music (preferences for this genre range from between $18.7 \%$ (2005) and $23.3 \%$ of the respondents (2017)); easy listening music (schlager), preferred by anywhere from $16.5 \%$ (2010) and $18.8 \%$ of the respondents (2017); newly composed folk music, preferred by $11.3 \%$ (2010) to $21.1 \%$ of the respondents (2015); rock music, which was the music genre of choice which in 2017 of $10.4 \%$ of the respondents, while in $201018.1 \%$ of the respondents; and pop music, ranging from $10.3 \%$ (2017) to $15.2 \%$ of the respondents (2015).

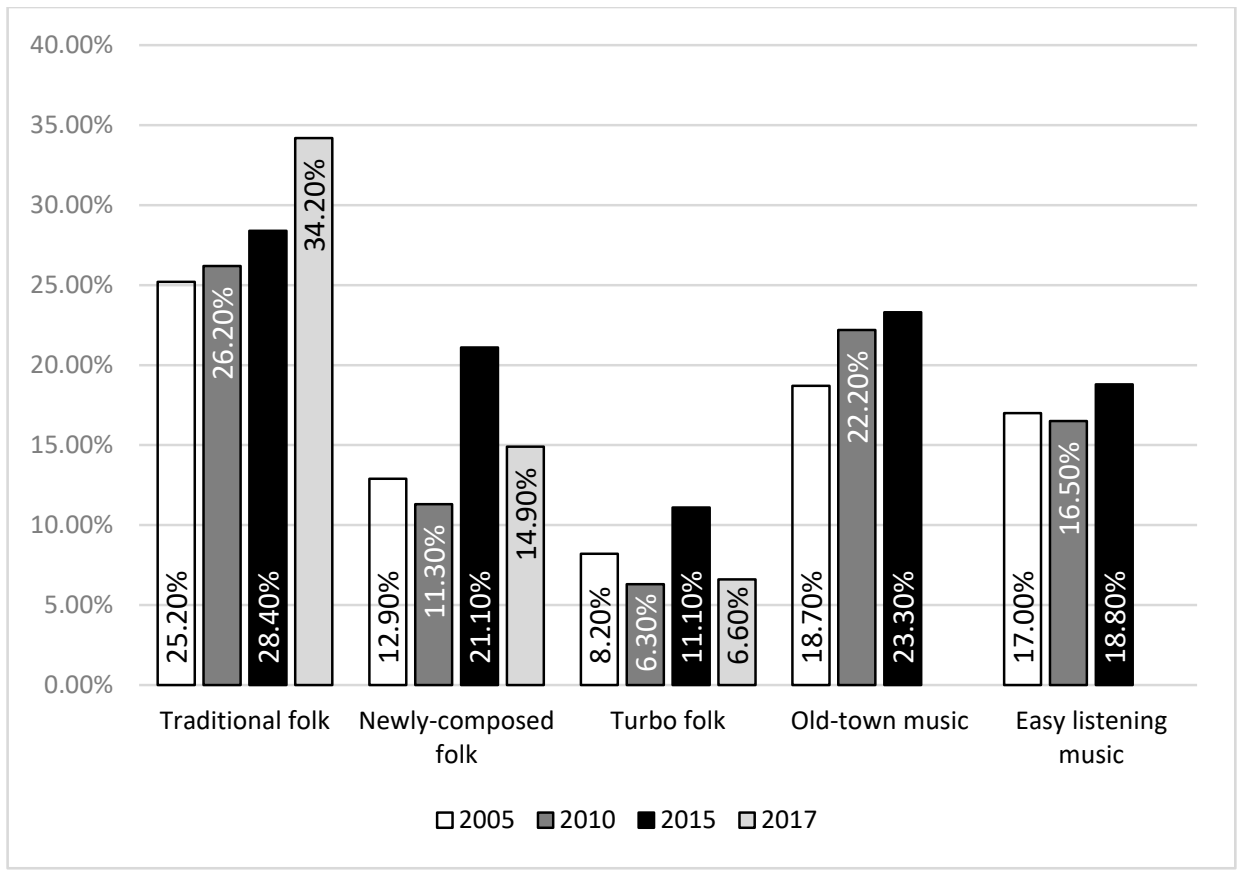

Fig. 1A Favorite music genres (2005 - 2017)

On the other hand, among the music genres towards which the respondents indicated a lower preference we find, from the local musical genres, turbo folk (from $6.3 \% 2010$ to $11.1 \%$ of the respondents in 2015) and, from the global musical genres, classical music (between $5.4 \%$ - 2017 and $8.1 \%$ of the respondents in - 2005) and jazz (from 3.7\% 2017 to $7.6 \%$ of the respondents in 2005 ).

The music genres least favored by the respondents include opera (from $3.7 \%$ to $3.9 \%$ of the respondents) and genres of contemporary popular music - such as dance/house $4.6 \%$ do $6.1 \%$ ), heavy metal (1.9\% do $5.3 \%)$, techno (2.3\% do $3.9 \%)$, hip-hop (2.0\% do $2.3 \%)$ and punk (1.6\% do $2.6 \%)$. 


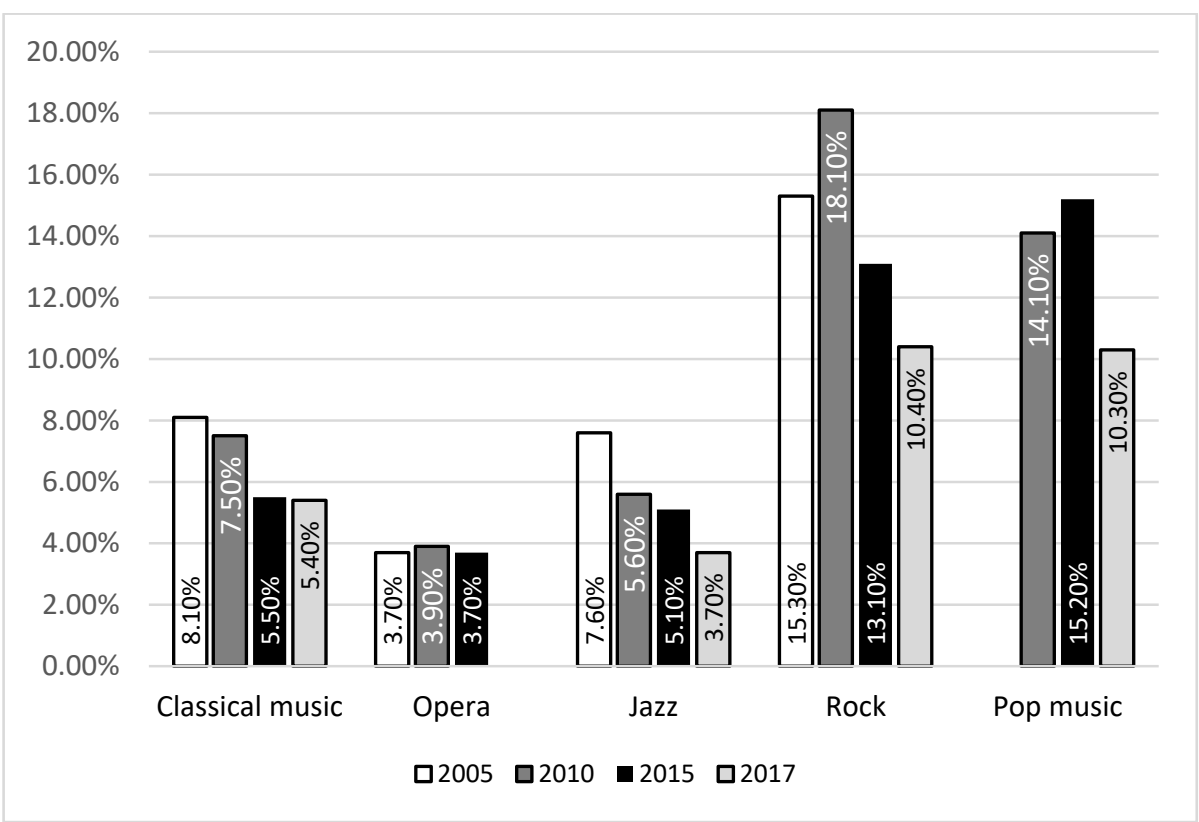

Fig. 1B Favorite music genres (2005 - 2017)

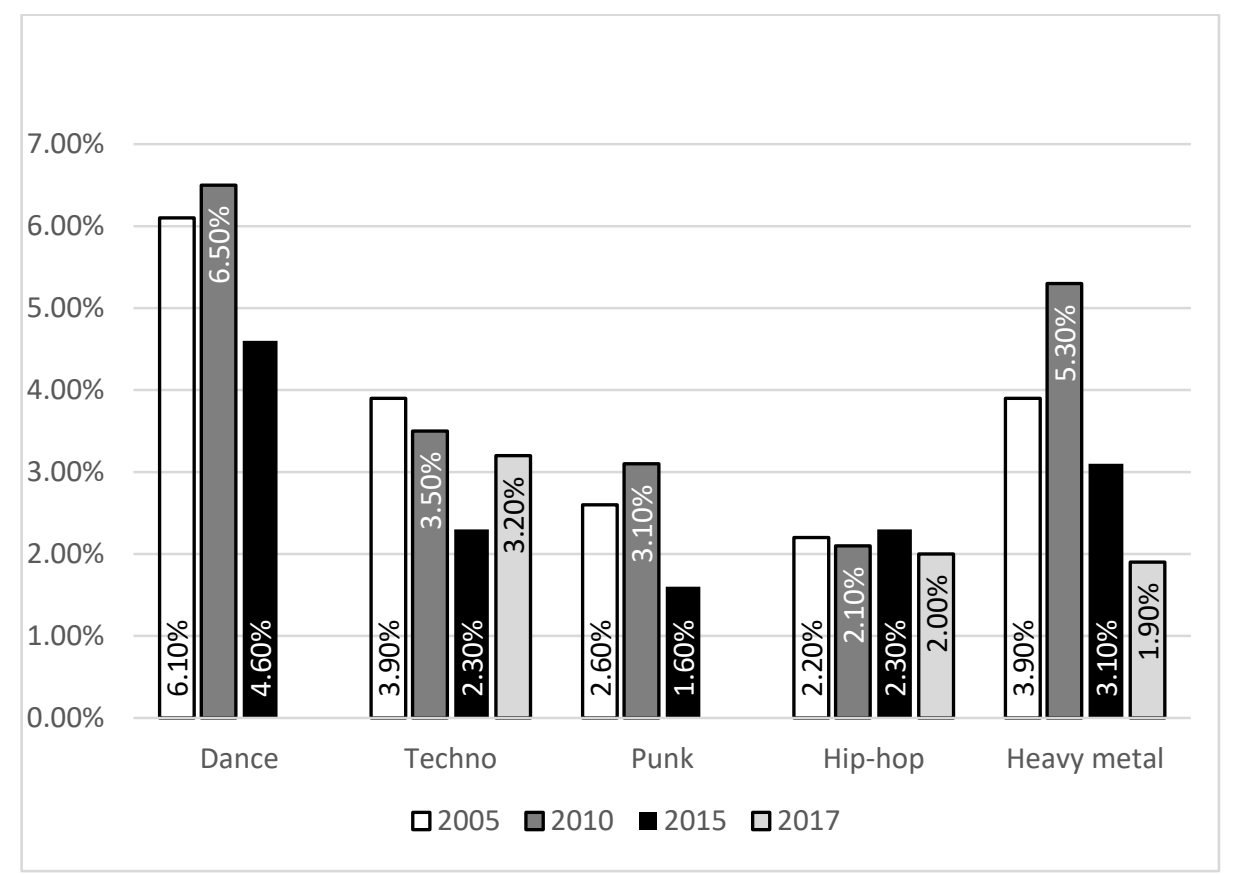

Fig. 1C Favorite music genres (2005 - 2017) 
The previous graphs represent only the percentage of the respondents who stated that they prefer certain music genres, but in all the studies we offered the respondents the possibility to express various attitudes in relation to each of these music genres, ranging from: a) I enjoy that very much; b) I like it; c) I do not mind hearing that; d) I do not like it; do e) It bothers me to hear it. As can be seen from graph $2^{4}$, there are music genres such as old town music, traditional folk music and easy listening music - which bother almost no one in Serbia, which do not divide the audience, while on the other hand there are those which polarize the audience quite strongly. For example, in the case of heavy metal, not only $42.5 \%$ of the respondents do not like this music, but another $25 \%$ cannot stand it ("It bothers me to hear it"). On the other hand, when it comes to turbo folk music, $26.5 \%$ do not like the genre, while another $12 \%$ are bothered when they hear it.

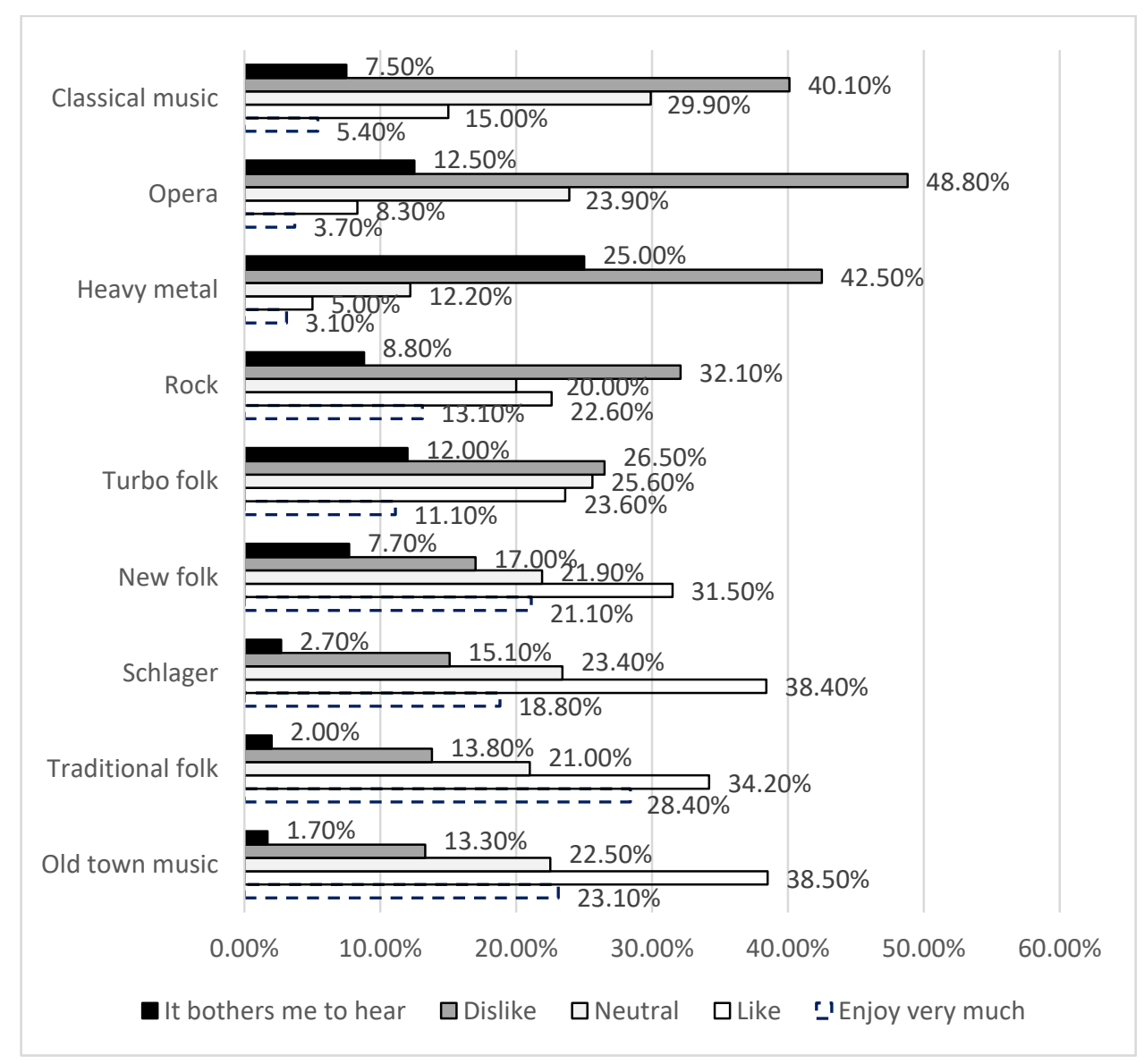

Fig. 2 Attitudes towards music genres (2015)

\footnotetext{
${ }^{4}$ Due to space limitations, this graph represents the full extent of the attitudes of the respondent in relation to the offered music genres from 2015. The complete results of all the studies are available upon request.
} 
Both opera and classical music belong to the group of polarizing music genres. When we focus only on them (Tables 1 and 2), we can see that the percentage of those who favored these genres ranges from $5 \%$ to $8 \%$ for classical music and approximately $4 \%$ for the opera. On the other hand, in all the studied years, almost $40 \%$ of the respondents to state that they do not like classical music, and between $6 \%$ and $8 \%$ cite that it bothers them to hear it. Opera is disliked by approximately $50 \%$ of the respondents, while $10 \%$ to $12 \%$ point out that it bothers them to hear it.

Table 1 Attitudes towards classical music

\begin{tabular}{lrrrrrrrr}
\hline Taste: Classical music & \multicolumn{2}{c}{2005} & \multicolumn{2}{c}{2010} & \multicolumn{2}{c}{2015} & \multicolumn{2}{c}{2017} \\
\hline This is the music that I like the most & 105 & $(8.2 \%)$ & 108 & $(7.6 \%)$ & 54 & $(5.5 \%)$ & 60 & $(5.5 \%)$ \\
I like to hear it & 269 & $(21.0 \%)$ & 330 & $(23.4 \%)$ & 150 & $(15.3 \%)$ & 199 & $(18.2 \%)$ \\
I do not mind hearing it & 349 & $(25.6 \%)$ & 433 & $(29.1 \%)$ & 299 & $(30.5 \%)$ & 322 & $(29.5 \%)$ \\
I do not like to hear it & 454 & $(35.4 \%)$ & 458 & $(32.4 \%)$ & 401 & $(41.0 \%)$ & 418 & $(38.3 \%)$ \\
It bothers me to hear it & 106 & $(7.8 \%)$ & 84 & $(5.9 \%)$ & 75 & $(7.7 \%)$ & 92 & $(8.4 \%)$ \\
\hline Total & 1283 & $(100 \%)$ & 1413 & $(100 \%)$ & 979 & $(100 \%)$ & 1091 & $(100 \%)$ \\
\hline
\end{tabular}

Table 2 Attitudes towards opera

\begin{tabular}{|c|c|c|c|}
\hline Taste: Opera & 2005 & 2010 & 2015 \\
\hline This is the music that I like the most & $48 \quad(3.8 \%)$ & $56 \quad(4.0 \%)$ & $37 \quad(3.8 \%)$ \\
\hline I like to hear it & $157(12.4 \%)$ & $177(12.6 \%)$ & $(8.5 \%)$ \\
\hline I do not mind hearing it & $300(23.7 \%)$ & $384(27.3 \%)$ & $239(24.6 \%)$ \\
\hline I do not like to hear it & $600(47.4 \%)$ & $638(45.4 \%)$ & $488(50.2 \%)$ \\
\hline It bothers me to hear it & $160(12.6 \%)$ & $150(10.7 \%)$ & $125(12.9 \%)$ \\
\hline Total & $1265(100 \%)$ & $1405(100 \%)$ & $972 \quad(100 \%)$ \\
\hline
\end{tabular}

We should, however, be careful when interpreting the obtained responses, especially from those respondents who cited that they like these two musical genres. Classical music and opera carry the 'aura' of a legitimate culture, something that every educated person should listen to and love, and it is probable that at least one part of those who cited that they enjoy classical music and the opera provided us with socially acceptable responses. On the other hand, quite a large number of those who do not like classical music and opera, especially those who are bothered by it, also indicated this vital feature - namely, that they function as indicators of high social status.

Unlike the Liberal-Humanist tradition in audience development which assumes that Culture and Art transcend class and other divisions in society, sociological studies have indicated that culture in practice is a means of marking and reproducing social divisions and distinctions. This is what Paul Di Maggio point to when he, echoing the attitudes of Douglas and Isherwood (Douglas and Isherwood, 1979, 12), cites that the uses of artistic tastes are social, that "they can be used as fences or bridges." (Di Maggio, 1987, 443). The same phenomenon is also pointed out by Pierre Bourdieu in his study Distinction: A Social Critique of the Judgement of Taste (1984 [1979]) when he makes the claim that "taste classifies, and it classifies the classifier" (Bourdieu, 1984, 6). According to Bourdieu, "to the socially recognized hierarchy of the arts, and within each of them, of genres, schools or periods, corresponds a social hierarchy of the consumers. This predisposes tastes to function as markers of "class'." (Bourdieu, 1984, 1-2). Tastes are a means for members of various social classes to be able to recognize each other, as well as to recognize those who belong to 
other classes. They can be used as "bridges" which connect members of the same classes, but can also become "fences" which prevent members of other classes from gaining access - to social contacts, but also resources, goods and favors. This largely hinders attempts at audience development ${ }^{5}$. Namely, the members of social classes often do not want to learn about and adopt the cultures of others, and especially of opposing classes - because they do not want to be culturally, what they socially are not.

\section{Education as a Prerequisite for the DeVelopment of TASte}

Unlike the standpoint that tastes - and especially tastes for legitimate culture - are innate, sociological research indicates that cultural practices, as well as aesthetic preferences are learned, and thus that they strongly correlate with the level of education and social background. According to Bourdieu, culture is acquired through three forms of education: education within the family, diffuse education which is accumulated in contact with other members of society, and institutional education which is realized through the educational system.

In an attempt to explain the advantage which children from families with highly educated parents who belong to higher social classes have in institutional education, Bourdieu developed the concept of cultural capital. According to him, cultural capital occurs in three basic states: the embodied state, the objectified state, and institutionalized state. In its embodied state, which according to Bourdieu represents its "fundamental state", cultural capital represents a group of cultivated dispositions which were acquired during the process of socialization. On the other hand, cultural capital in its objectified states includes material objects and the media - such as images, books, sculptures, monuments, instruments or apparatuses which are used for cultural consumption. Finally, the third state in which cultural capital emerges is the institutionalized state, in the form of educational and academic diplomas.

In the studies Bourdieu worked on with J-C. Passeron ${ }^{6}$, it was indicated that schools are not socially neutral facilities, but instead that their programs and means of evaluation are based on the culture of dominant classes. Children who come from these families - even though they are not openly favored in schools - are at an advantage, since activities are taking place on a terrain that they are familiar with. On the other hand, children from working class families must at the same time learn to manage both these cultural (linguistic, social) codes and school material. Even when they are successful at it, they rarely manage to achieve the ease and naturalness that characterizes students socialized in this culture.

Even enjoying art requires knowledge of cultural codes, which are acquired unnoticeably, during primary socialization in the earliest days of childhood, and the circle of the family. Those lacking this type of knowledge, feel lost in a chaos of sounds and rhythms, colors and lines before works of art. Cultural participation thus emerges as practical knowledge of deciphering cultural codes, which is mostly acquired through contact with artworks, thus through implicit learning. From there comes the great importance of the institutional education, in which especially those children lacking this knowledge, could master the codes they need to enjoy art.

\footnotetext{
${ }^{5}$ See: Kawashima (2000) and Tomka (2016).

${ }^{6}$ The results of which are presented in the book Reproduction in Education, Society and Culture (Bourdieu and Passeron, 1977 [1970]).
} 
The influence that social mechanisms exert on the formation of taste can be seen both on the examples of classical music indicating a belonging to the upper social strata of experts and managers and newly composed folk music, which in Serbia and the Yugoslavia since the 1960s indicates - in the opposite direction - a belonging to the working class and class of agricultural workers. Even simple cross-tabulations indicate that educated members of higher social classes do not like, or are even disgusted, by newly composed folk music, just like the members of classes poor in capital do not like and have a problem with classical music (see Tables $3-6$ ).

In the case of classical music (Tables 3 and 4), it can be seen that the respondents with a higher education are almost two and a half times more likely to like classical music than those with an elementary education, and they are two and a half times less present in the group of those who do not like it. In addition, among those who like classical music, there are almost three times as many managers and experts than there are laborers and agricultural workers. And there are two and a half times more agricultural workers in the group of respondents who do not like it.

Table 3 Cross-tabulation: respondents' education and attitudes towards classical music (2015)

\begin{tabular}{lcccc}
\hline & $\begin{array}{c}\text { Elementary education } \\
\text { of less }\end{array}$ & $\begin{array}{c}\text { High school } \\
\text { education }\end{array}$ & $\begin{array}{c}\text { College or higher education } \\
\text { (BA, MA, PhD) }\end{array}$ & Total \\
\hline Like & $26(12.7 \%)$ & $107(52.5 \%)$ & $71(34.8 \%)$ & $204(100 \%)$ \\
Neutral & $12.9 \% \%$ & $19.9 \%$ & $29.8 \%$ & $20.8 \%$ \\
& $43(14.4 \%)$ & $157(52.5 \%)$ & $99(33.1 \%)$ & $299(100 \%)$ \\
Dislike & $21.3 \%$ & $29.1 \%$ & $41.6 \%$ & $30.5 \%$ \\
Total & $133(27.9 \%)$ & $275(57.8 \%)$ & $68(14.3 \%)$ & $476(100 \%)$ \\
& $65.8 \%$ & $51.0 \%$ & $28.6 \%$ & $48.6 \%$ \\
& $202(20.6 \%)$ & $539(55.1 \%)$ & $238(24.3 \%)$ & $979(100 \%)$ \\
\multicolumn{5}{c}{$100 \%$} \\
$\chi^{2}(4)=63.820, \mathrm{p}<0.001$ \\
\end{tabular}

Table 4 Cross-tabulation: respondents' occupation and attitudes towards classical music (2015)

\begin{tabular}{lcccc}
\hline & Farmers and workers & Clerks and technicians & Experts and managers & Total \\
\hline Like & $74(39.8 \%)$ & $47(25.3 \%)$ & $65(34.9 \%)$ & $186(100 \%)$ \\
& $15.4 \%$ & $21.6 \%$ & $39.2 \%$ & $21.5 \%$ \\
Neutral & $141(50 \%)$ & $80(28.4 \%)$ & $61(21.6 \%)$ & $282(100 \%)$ \\
& $29.4 \%$ & $36.7 \%$ & $36.7 \%$ & $32.6 \%$ \\
Dislike & $265(66.9 \%)$ & $91(23.0 \%)$ & $40(10.1 \%)$ & $396(100 \%)$ \\
& $55.2 \%$ & $41.7 \%$ & $24.1 \%$ & $45.8 \%$ \\
Total & $480(55.6 \%)$ & $218(25.2 \%)$ & $166(19.2 \%)$ & $864(100 \%)$ \\
& $100 \%$ & $100 \%$ & $100 \%$ & $100 \%$ \\
\hline \multicolumn{5}{c}{$\chi^{2}(4)=62.929, \mathrm{p}<0.001$} \\
\end{tabular}

On the other hand, in table 5 one can see that respondents with an elementary or even lower education, in terms of percentages, are three times as likely to like newly composed folk music than are those with a higher education, as well as the fact that among the highly educated, there are five times as many of those who do not like this music than 
among the respondents with an elementary education. Similarly, among agricultural workers and laborers there are two and a half times as many of those who like folk music than among those who belong to the groups of experts and managers, and vice versa, there are almost two and a half times as many of those who do not like folk music in this latter group than there are among the laborers and agricultural workers (Table 6).

Table 5 Cross-tabulation: respondents' education and attitudes towards newly-composed folk music (2015)

\begin{tabular}{lcccc}
\hline & $\begin{array}{c}\text { Elementary education } \\
\text { of less }\end{array}$ & $\begin{array}{c}\text { High school } \\
\text { education }\end{array}$ & $\begin{array}{c}\text { College or higher education } \\
\text { (BA, MA, PhD) }\end{array}$ & Total \\
\hline Like & $166(31.6 \%)$ & $292(55.5 \%)$ & $68(12.9 \%)$ & $526(100 \%)$ \\
Neutral & $77.2 \%$ & $54.0 \%$ & $28.8 \%$ & $53.0 \%$ \\
Dislike & $30(13.7 \%)$ & $121(55.3 \%)$ & $68(31.1 \%)$ & $219(100 \%)$ \\
Total & $14.0 \%$ & $22.4 \%$ & $28.8 \%$ & $22.1 \%$ \\
& $19(7.7 \%)$ & $128(51.8 \%)$ & $100(40.5 \%)$ & $247(100 \%)$ \\
& $8.8 \%$ & $23.7 \%$ & $42.4 \%$ & $24.9 \%$ \\
& $215(21.7 \%)$ & $541(54.5)$ & $236(23.8)$ & $992(100 \%)$ \\
& $100 \%$ & $100 \%$ & $100 \%$ & $100 \%$ \\
\hline
\end{tabular}

Table 6 Cross-tabulation: respondents' occupation and attitudes towards newly-composed folk music (2015)

\begin{tabular}{lcccc}
\hline & Farmers and workers & Clerks and technicians & Experts and managers & Total \\
\hline Like & $304(69.2 \%)$ & $93(21.2 \%)$ & $42(9.6 \%)$ & $439(100 \%)$ \\
Neutral & $62.2 \%$ & $21.2 \%$ & $25.6 \%$ & $50.4 \%$ \\
& $93(46.0 \%)$ & $59(29.2 \%)$ & $50(24.8 \%)$ & $202(100 \%)$ \\
Dislike & $19.0 \%$ & $27.1 \%$ & $30.5 \%$ & $23.2 \%$ \\
Total & $92(40.4 \%)$ & $66(28.7 \%)$ & $72(31.3 \%)$ & $230(100 \%)$ \\
& $18.8 \%$ & $30.3 \%$ & $31.3 \%$ & $43.9 \%$ \\
& $489(56.1 \%)$ & $218(25.0 \%)$ & $164(18.8 \%)$ & $871(100 \%)$ \\
\multicolumn{5}{c}{$\chi^{2}(4)=75.791, \mathrm{p}<0.001$} \\
\end{tabular}

These tendencies were also checked using a Multiple Correspondence Analysis (MCA) and binominal logistic regression. In the case of the Multiple Correspondence Analysis, the active variables that were used included attitudes towards music genres. On the maps a positive attitude towards music genres (like) was marked with plus signs (for example, Folk ++), a neutral attitude was marked with a plus/minus sign (for example, Rock +/-) and a negative attitude (dislike) with minus signs (for example, Classics --).

On the maps created using the MCA for all four studied years, the musical tests were grouped into the same three clusters. On the Figure 3, which shows the results from 2005, one can see that on the left side there are grouped tastes which express a positive attitude towards local musical forms (traditional folk music, newly composed folk music, turbo folk, old time music and easy listening music), and a negative attitude toward global musical forms (ranging from classical music, opera and jazz, to rock, punk, hip-hop and heavy metal). 
In the lower right-hand quadrant, contrary to this, one finds clustered tastes which expresses a positive attitude towards global music forms (again ranging from classical music to heavy metal) and negative attitudes toward local cultural forms. In the upper right-hand quadrant, the tastes of individuals that could be referred to as omnivores are grouped. They claim that they "don't mind hearing" any of these types of music, similarly to those who say they like to hear any good music.

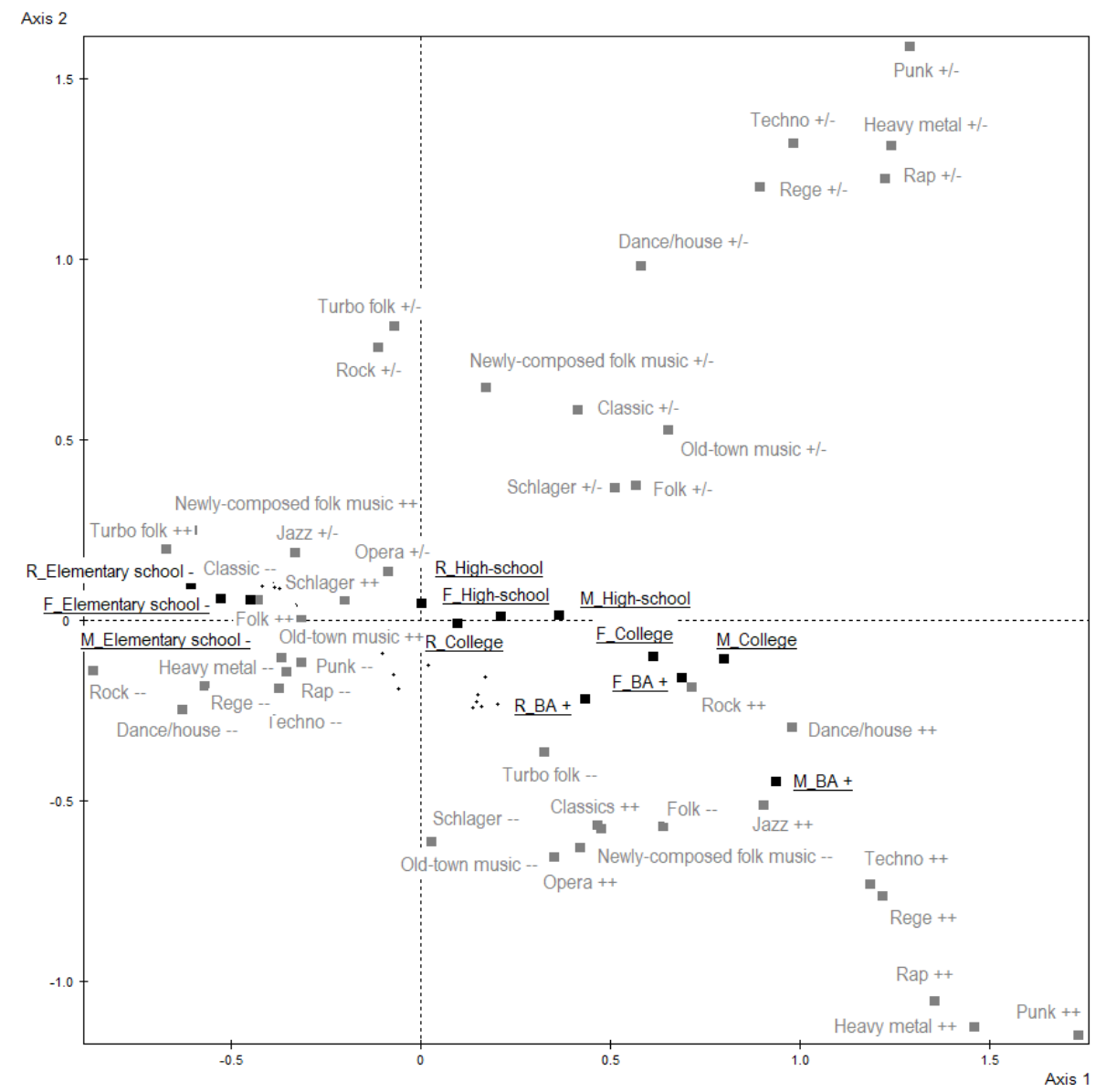

Fig. 3 Map of taste with supplementary indicators of education projected (2005)

Onto the maps that were constituted by relations between these musical tastes, we projected the level of education of the respondents, as well as the level of education of their fathers and mothers. As can be seen in Figure 3, the cluster that is characterized by preferences for exclusively local musical forms, is at the same time characterized by the elementary education of the respondents and the elementary or incomplete elementary education of their parents. On the other hand, in the lower right-hand part of the map, where the preferences for global music forms are grouped, one finds indicators of higher 
education both of the respondents and their parents (a university education, completed master's thesis, doctoral dissertation). Indicators of a high school education of both the respondents and their parents emerged as closest to the indicators of tastes of those whom we marked as omnivores.

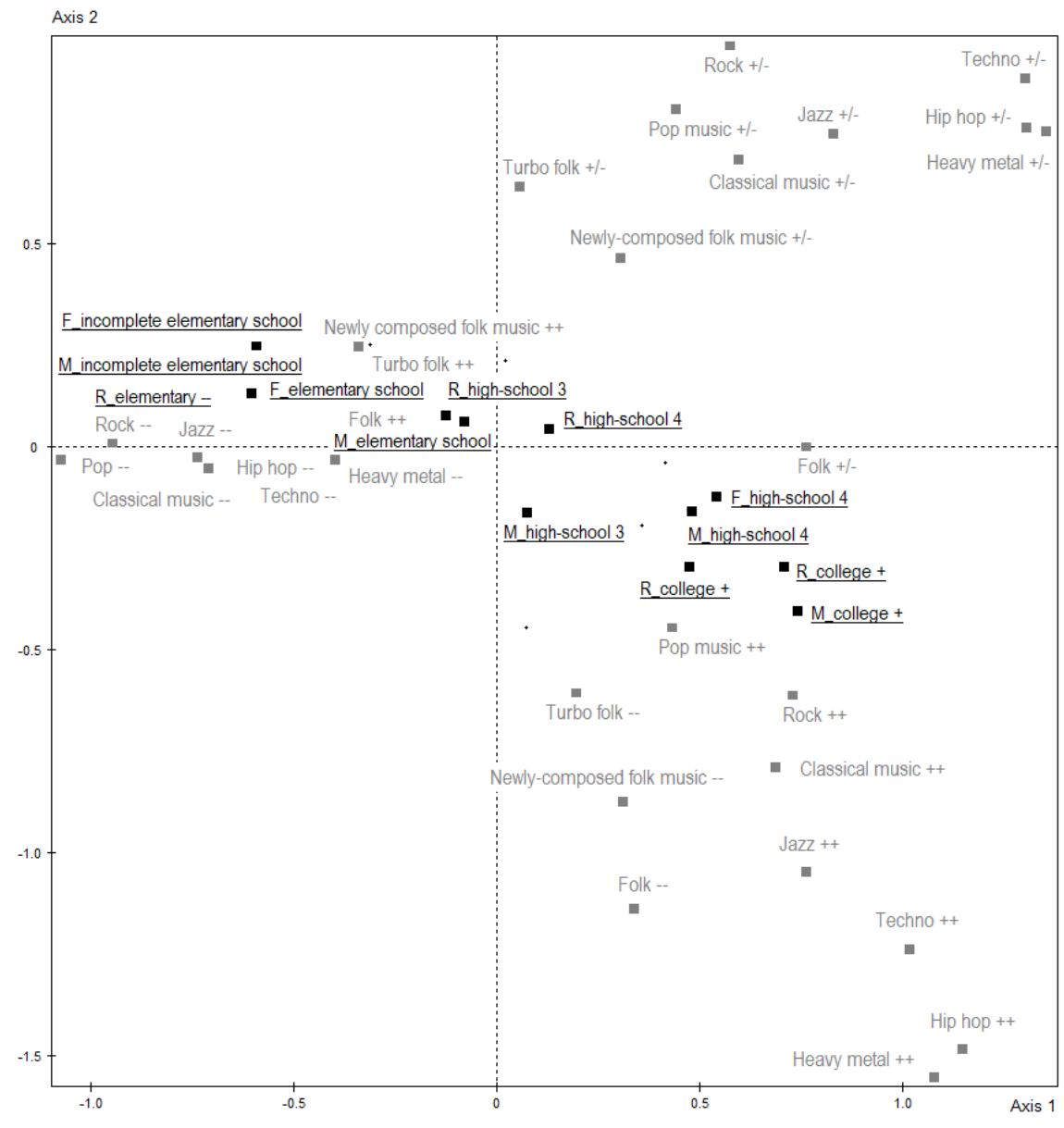

Fig. 4 Map of tastes with supplementary indicators of education projected (2017)

On the Figure 4, based on the results from 2017, very similar results were obtained as those from 2005. On the left-hand side of the map one finds grouped indicators of the musical tastes which indicate a preference for local musical forms (traditional folk music, newly composed folk music, turbo folk) and a dislike of music genres which belong to the global cultural offer (classical music, opera, jazz, rock, pop music, hip-hop, techno, heavy metal). In this part of the map, we also find grouped indicators of elementary education of the respondents and the elementary or incomplete elementary education of their parents.

In the lower right-hand quadrant of the map, there are positive attitudes toward global music genres and a negative attitude towards the studied local musical forms (traditional folk 
music, newly composed folk music and turbo folk). At the same time, in this section of the map one also finds supplementary indicators of a high school education of the respondents' parents (a four-year high school education of both the father and mother, and a three-year high school education of the mothers), as well as community college education or higher levels of education (BA, MA, $\mathrm{PhD}$ ) both of the respondents and their parents. A high school education of the respondents (both a three- and four-year education) is closest on the map to tastes that are characterized by the readiness to listen to both local and global musical forms, but without any special enthusiasm for either.

These tendencies, that tastes for classical music are closely associated with high education levels, were checked using a binomial regression analysis. The tastes were recoded into two categories: like and dislike. As predictors we used the gender, age of the respondents, their place of permanent residence, average monthly household income per household member and their level of education as well as that of their parents.

The results of the analyses confirm the importance of education for the development of taste for classical music: the respondents with a high-school level of education, and particularly those with higher levels of education $(\mathrm{BA}, \mathrm{MA}, \mathrm{PhD})$ have significantly greater chances of liking classical music (compared to those respondents with an elementary education) based on the results from 2005 and 2017. This also refers to individuals whose parents have a high school education (for both analyzed years) and especially those whose fathers have a college or university education (in the study dating from 2017). It is interesting that the level of education of the mothers of the respondents, according to our results, has no significant influence on the development of taste for classical music among the respondents. In the research from 2015, living in big cities was also identified as a significant predictor, and in the research from 2017, the age of the respondents - namely those older than 46 had a greater chance of liking this musical genre than the younger respondents. What is also interesting is that, based on the results we have obtained - and this was confirmed by the results of other studies - the level of household income has no direct impact on musical taste.

Table 7 Binominal logistic regression analysis

\begin{tabular}{|c|c|c|c|c|}
\hline \multirow[b]{3}{*}{ Gender: Male (ref = female) } & \multicolumn{2}{|c|}{ Classical music 2015} & \multicolumn{2}{|c|}{ Classical music 2017} \\
\hline & $\operatorname{Exp}(B)$ & CI & $\operatorname{Exp}(B)$ & CI \\
\hline & 1.430 & $.950-2.154$ & 1.173 & $.749-1.836$ \\
\hline \multicolumn{5}{|l|}{$\mathrm{Age}^{1}$} \\
\hline Age $31-45$ years & 1.259 & $.606-2.616$ & .976 & $.456-2.092$ \\
\hline Age $46-65$ years & 1.063 & $.500-2.259$ & $3.095^{* *}$ & $1.423-6.733$ \\
\hline $65+$ & 1.682 & $.713-3.966$ & $4.702^{* * *}$ & $1.946-11.359$ \\
\hline \multicolumn{5}{|l|}{ Education level $^{2}$} \\
\hline High-school & 1.702 & $.887-3.268$ & 2.029 & $.977-4.216$ \\
\hline Collage & $2.217^{*}$ & $1.033-4.759$ & $3.703^{* *}$ & $1.588-8.636$ \\
\hline \multicolumn{5}{|l|}{ Fathers education } \\
\hline High school & $1.730^{*}$ & $1.023-2.923$ & $3.019^{* * *}$ & $1.653-5.514$ \\
\hline Collage & 1.489 & $.672-3.301$ & $7.484^{* * *}$ & $3.270-17.125$ \\
\hline \multicolumn{5}{|l|}{ Mothers education } \\
\hline High-school & .874 & $.490-1.562$ & 1.601 & $.842-3.045$ \\
\hline Collage & 1.287 & .533-3.109 & 2.107 & $.658-6.753$ \\
\hline
\end{tabular}




\begin{tabular}{lrrrr}
\hline Towns/middle size cities & 1.548 & $.943-2.543$ & 1.064 & $.654-1.731$ \\
Big cities & $2.315^{* *}$ & $1.253-4.279$ & .877 & $.423-1.821$ \\
\hline Income 4 & & & & \\
\hline $101-150$ EUR & .786 & $.408-1.514$ & .776 & $.384-1.570$ \\
$151-200$ EUR & 1.095 & $.588-2.038$ & .751 & $.377-1.496$ \\
$201-300$ EUR & 1.387 & $.746-2.577$ & 1.123 & $.563-2.241$ \\
300 EUR + & 1.213 & $.592-2.482$ & 1.658 & $.707-3.885$ \\
\hline
\end{tabular}

Notes: $\mathrm{Cl}-95 \%$ confidence interval for $\operatorname{Exp}(\mathrm{B})$, level of significance $* \mathrm{p}<0.05 ; * * \mathrm{p}<0.01$

${ }^{1} 18-30$ years is the reference category

${ }^{2}$ Elementary school is the reference category

${ }^{3} \mathrm{Rural}$ area/village is the reference category

${ }^{4}$ Income $<100$ EUR is the reference category

Cox \& Snell R Square $=0.068$, Nagelkerke R Square $=0,105$ (classical music 2015)

Cox \& Snell R Square=0.151, Nagelkerke R Square=0,234 (classical music 2017)

\section{AUDIENCE DEVELOPMENT FOR CLASSICAL MUSIC IN SERBIA}

The obtained results indicate the strong influence of formal education on the development of musical taste, especially on the development of preferences for classical music and the opera. They also confirm that musical tastes, in a social sense, are much more than a simple expression of aesthetic preferences. In discussions of taste, according to Herbert Gans, the stakes are actually much higher. The nature of these discussions has to do with the nature of good life and especially of what culture and whose culture should be dominant in society. Thus, according to Bourdieu, they represent a form of class struggle. The members of the dominant classes, by adopting the "charismatic ideology", that is, the standpoint that tastes are inborn and the result of personal endowments, see taste as a way of legitimizing their social position. Namely, their refined tastes, contrary to the vulgar tastes of the lower classes, reaffirm that their dominant position in society is not only an accident which rendered them wealthy and powerful, but that they are also "better men" who deserve such a social position. On the other hand, members of the lower classes are exposed, according to Bourdieu, to "symbolic violence" - they, especially through the system of education, have the culture of the dominant classes imposed upon them as the legitimate one, which reproduces the existing systems of power.

It would be easy enough to take for granted the results of these analyses based on the research of the societies of Western Europe and the US from the 1960s and 1970s, but the context in which the activities of audience development should take place in Serbia in the 2020 s is radically different. In their social function, tastes in Serbia are nothing less than symbolic weapons in class struggles. The main difference is that the elite culture (and among these practices also tastes related to classical music, the opera, ballet) in Serbia is not the culture of the dominant class. During the past few decades, Serbia has been dominated by a particular form of escapist popular culture (whose typical products are newly composed folk music, turbo folk, reality shows, Latin American and Turkish soap operas), which is shared by the members of the lower classes and the members of the dominant class. Irrespective of whether the members of the dominant class actually experience this culture as their own or simply use it for manipulation, this culture, seemingly contrary to Bourdieu's standpoint, still contributes to the legitimization of their rule - only this time not because they are better, but because they are supposedly the same as the people whom they rule. This indirectly confirms 
Bourdieu's concept that all cultural systems are arbitrary and that the dominance of any one of them in societies essentially depends on the powers that stand behind them.

Therefore, the role of audience development for classical music in our social context is different. The starting points in its planning should be the insight that all culture is learned, and the question of where members of younger generations in Serbia can learn the codes needed for enjoying classical music.

One of the basic shortcomings of studies of cultural participation is the absence of parallel studies in cultural offer, which, as a rule, leads to the incorrect interpretation of the results. When analyzing the prerequisites for audience development in our country, one should bear in mind that the offer of classical music in Serbia is quite limited. Continued offer of the opera in Serbia can only be found in Belgrade and Novi Sad, with occasional concerts in Niš and Kragujevac, while classical music concerts are also a part of the cultural offer only in some of the largest cities. Everyone else is simply excluded from the possibility of participating in them. Furthermore, it is quite rare to come across a classical music concert or opera being broadcast on television or radio station with a national frequency. Therefore, the Music Culture curriculum in elementary and high schools is practically the only source for acquiring competences for communicating with classical music and opera for the broadest segments of the population at an early age.

It is clear that the first step in audience development for classical music must be the improvement of its offer in Serbia. Without that, it is difficult to imagine there will be an audience for classical music. The second important lesson to be drawn from the studies which dealt with audience development is that in order for it to be successful, audience development must begin early on, in childhood, must last for a very long time, and be continuous. Thirdly, based on the insight that cultural participation requires practical knowledge needed to decipher cultural codes, which is mostly acquired through contact with artworks, it would be desirable for Musical Culture courses to be focused on acquiring these practical skills, and less on acquiring theoretical knowledge on the history of art or musical instruments. Four, it would be important for teachers working in elementary and secondary schools not to forget that musical tastes have important symbolic aspects and that they can strengthen social divisions. Especially when working with children from working class families and children of agricultural workers, it should be borne in mind that this is a music culture which is mostly alien to them and that additional effort must be made for them to become acquainted with its cultural codes. On the other hand, it would be good, bearing in mind the symbolic aspects of musical tastes, that those in charge of designing the programs for this course, introduce the study of other music genres as well, including traditional folk music or old town music.

If the latent function of education is to legitimize class differences, its manifest function is emancipatory. In our environment, there is little danger that coming into contact with classical music, opera and ballet would contribute to the legitimization of the rule of dominant groups. It is more likely that it might have a critical function. Certainly, the task of musical education is to introduce the pupils with various cultural forms and with various cultural codes, and not to impose them on the students. However, it is precisely this function of becoming acquainted with other cultures and other cultural forms that is exceptionally important, in particular for the globalized world that is fast approaching, and in which knowledge only of the local culture will not suffice. 


\section{REFERENCES}

Bourdieu, P. and Passeron, J-C. (1977) [1970]. Reproduction in Education, Society and Culture. London: Sage. Bourdieu, P. (1984) [1979]. Distinction: A Social Critique of the Judgement of Taste. London: Routledge \& Kegan Paul.

Chan, T. W and Goldthorpe, J. H. (2006). Social Stratification and Cultural Consumption: Music in England. European Sociological Review, 23(1), 1-19.

Chan, T. W. (2019). Understanding cultural omnivores: social and political attitudes. The British Journal of Sociology, 70(3), 784-806.

Cvetičanin, P. (2007). Kulturne potrebe, navike i ukus građana Srbije i Makedonije [Cultural Needs, Habits and Tastes of the Citizens of Serbia and Macedonia], Niš: Odbor za građansku inicijativu

Cvetičanin, P. and Milankov, M. (2011a). Kulturne prakse građana Srbije [Cultural Practices of the Citizens of Serbia], Beograd: Zavod za proučavanje kulturnog razvitka

Cvetičanin, P. and Popescu, M. (2011b). The Art of Making Classes in Serbia: Another Particular Case of The Possible. Poetics, 39(6), 444-468.

Cvetičanin, P. (ed.) (2012). Social and Cultural Capital in Serbia, Niš: Centar za empirijske studije kulture jugoistočne Evrope.

Douglas, M., and Isherwood, B. (1979). The World of Goods. New York: Basic Books.

Flemmen, M.P, Jarness, V. and Rosenlund, L. (2019). Class and status: on the misconstrual of the conceptual distinction and a neo-Bourdieusian alternative. The British Journal of Sociology, 70(3), 816-866.

DiMaggio, P. (1987). Classification in Art American Sociological Review, 52(4), 440-455.

Gans, H. J. (1999). Popular Culture and High Culture: An Analysis and Evaluation of Taste (revised edition). New York: Basic Books.

Kawashima, N. (2000). Beyond the Division of Attenders vs. Non-attenders: a study into audience development in policy and practice. Warwick: Centre for Cultural Policy Studies, University of Warwick.

Peterson, R. A. (1992). Understanding audience segmentation: From elite and mass to omnivore and univore. Poetics, 21, 243-258.

Peterson, R. A. and Simkus, A. (1992.). How musical tastes mark occupational status groups. In M. Lamont and M. Fournier (Eds.), Cultivating differences: Symbolic boundaries and the making of inequality (pp. 152186). Chicago: The University of Chicago Press.

Peterson, R. A. and Kern, R.M. (1996). Changing highbrow taste: From snob to omnivore. American Sociological Review, 61(5), 900-907.

Peterson, R. A. (2005). Problems in comparative research: The example of omnivorousness. Poetics, 33(5-6), 257-282.

Tomka, G. (2016). Guidebook for hopefully seeking the audience. IETM, Retrieved on June 3, 2019, from the World Wide Web: https://www.ietm.org/en/publications/audience-explorations-guide-book-for-hopefullyseeking-the-audience

\section{OBRAZOVANJE KAO ČINILAC RAZVOJA MUZIČKOG UKUSA}

U ovom tekstu, baziranom na anketnim istraživanjima kulturnih praksi građana Srbije iz 2005, 2010, 2015. i 2017. godine kojima je rukovodio autor članka, analiziran je uticaj obrazovanja ispitanika $i$ njihovih roditelja na razvoj muzičkog ukusa ispitanika. U uvodnom delu teksta ukratko su izložena tri sociološka stanovišta o odnosu ukusa i pripadnosti društvenim kolektivitetima čiju smo primenljivost testirali u istraživanjima kulturnih praksi u Srbiji. U nastavku su dati rezultati longitudinalnog istraživanja izraženih preferenci za različite tipove muzičkih žanrova u Srbiji i stavova koje su ispitanici imali prema mnogostrukim muzičkim žanrovima koje smo analizirali u ovim studijama. U trećem delu teksta, fokusirali smo se na rezultate istraživanja koji se odnose na klasičnu muziku i operu i analizirali koji društveni činioci utiču na formiranje estetskih preferenci za ove muzičke žanrove u Srbiji. $U$ zaključku je ukratko ukazano na implikacije nalaza za aktivnosti razvoja publike za klasičnu muziku, koja se uglavnom izučava u okviru predmeta „,Muzička kultura" u osnovnim i srednjim školama. Oni se odnose na neophodnost poboljšanja kulturne ponude u lokalnim zajednicama; potrebu da se sa aktivnostima razvoja publike počne rano u detinjstvu i da budu kontinuirane; na važnost toga da učitelji $i$ nastavnici budu svesni simboličkih aspekata muzičkih ukusa koji se odnose na društvene podele; i na fokus na sticanje, kod dece, veština dešifrovanja kulturnih kodova, a ne toliko na usvajanje teorijskih znanja u oblasti istorije umetnosti ili znanja o muzičkim instrumentima.

Ključne reči: muzički ukus, klasična muzika, obrazovanje, razvoj publike 